http://jmscr.igmpublication.org/home/ ISSN (e)-2347-176x ISSN (p) 2455-0450 crossref DOI: https://dx.doi.org/10.18535/jmscr/v9i1.32

\title{
Diabetic Ketoacidosis Associated with Guillain-Barre Syndrome
}

Authors

\author{
Katyayani Dutt ${ }^{1}$, Maninder Singh ${ }^{2}$, Bhagwan Dass Negi*
}

${ }^{1}$ MD Medicine, Junior Resident. Deptt of Medicine, DR R.P.G.M.C Tanda, Kangra. H.P, India

${ }^{2}$ MD Anaesthesia, Junior Resident. Deptt of Medicine. Dr R.P.G.M.C Tanda, Kangra. H.P India

${ }^{3}$ MD Medicine, Junior Resident Deptt of Medicine, Dr R.P.G.M.C Tanda, Kangra H.P India

*Corresponding Author

Bhagwan Dass Negi

\section{Abstract}

GBS is an acute, frequently severe and fulminant polyradiculoneuropathy that is autoimmune in nature. There has been few case reports in literature of DKA as manifestation of GBS. We are reporting a case of young female with history of dm presented to us with diabetic ketoacidosis and GBS.

Keywords: diabetic ketoacidosis, Guillian barre syndrome.

\section{Introduction}

GBS is an acute, frequently severe, and fulminant polyradiculoneuropathy that is autoimmune in nature. GBS is the major cause of acute neuromuscular paralysis, with an annual incidence of 1-2 per 100,000 worldwide. ${ }^{1,2} 70 \%$ of cases of GBS occur 1-3 week after an acute infectious process, usually respiratory or gastrointestinal. GBS association has been seen post h1n1 vaccination, lymphoma, SLE, HIV- seropositive individuals. ${ }^{3}$ Electrodiagnostically GBS has various variant, the most common is acute inflammatory demyelinating polyneuropathy (AIDP). Other variants are acute motor axonal neuropathy (AMAN), acute motor sensory axonal neuropathy (AMSAN), Miller fisher syndrome. ${ }^{3}$ Here we are presenting a case of female who presented to us as diabetic ketoacidosis with GBS. This is an extremely rare presentation and only few case reports are there.

\section{Case Report}

A 27 year female presented in emergency on $5^{\text {th }}$ October 2019 with history of decreased responsiveness for 1 day and vomiting for 1 day. There was no history of loose stool, fever, abdominal pain, seizures. She was a known diabetic for 5 year and was on insulin but was non complaint. On examination her bp was $90 / 60 \mathrm{~mm}$ of hg. Her pulse rate was 100 . Her random blood sugar was $583 \mathrm{mg} / \mathrm{dl}$. Her GCS was, dtr were preserved and rest of other system were normal. Her investigation were sent and as shown in table $1 \mathrm{ABG}$ was suggestive of metabolic acidosis (ph: 7.0 pco2 21.4 hco3 10 po2 108) and serum osmolarity was high. Urine for ketones were present. She was admitted to intensive care unit as DKA and managed with fluids, insulin infusion, iv antibiotics. on routine investigation she had anaemia for which her anemia work up was sent. Her Hba1c, C peptide and GAD 65 was also sent 
(table 2). On day 5 of admission she started complaining of difficulty in moving lower limbs which progressed to upper limb. Her mental status and cranial nerves were within normal limit. Her power in upper limb was $2 / 5$ and lower limb was 1/5 .Her DTR were absent. Her serum potassium was sent which was 4.3 meq. Her NCS was suggestive of AMSAN variant. Her CSF was done, total cell were 5 (neutrophill were 10, lymphocyte were 90) csf protein 123, csf sugar 82 and ADA was negative. Based on clinical and laboratory findings she was diagnosed as GBS. Intravenous immunoglobulin $15 \mathrm{gm}$ was given for 5 days and patient was advised physiotherapy. On day 22 her weakness improved to power in upper limb to $4 / 5$ and lower limb to $2 / 5$ and after discharge she continued rehabilitation and insulin therapy.

Table 1

\begin{tabular}{|l|c|c|c|}
\hline Hemoglobin & $8 \mathrm{~g} / \mathrm{dl}$ & Sgpt & $24.5 \mathrm{u} / \mathrm{l}$ \\
\hline Tlc & $\begin{array}{c}12.6 \\
\text { thous/ul }\end{array}$ & Alkpo4 & $129 \mathrm{u} / \mathrm{l}$ \\
\hline Platelet & $\begin{array}{c}303 \\
\text { thou/ul }\end{array}$ & Sodium & $145 \mathrm{mmol} / \mathrm{l}$ \\
\hline $\mathrm{p} / \mathrm{s}$ & $\mathrm{NCNC}$ & Potassium & $3 \mathrm{mmol} / 1$ \\
\hline Urea & $35 \mathrm{mg} / \mathrm{dl}$ & Chloride & $114.50 \mathrm{mmol} / 1$ \\
\hline Creatinine & $0.6 \mathrm{mg} / \mathrm{dl}$ & Protein total & $6 \mathrm{~g} / \mathrm{dl}$ \\
\hline Bilirubin & $\begin{array}{c}0.21 \\
\mathrm{mg} / \mathrm{dl}\end{array}$ & $\begin{array}{c}\text { Albumin } \\
2.4 \mathrm{~g} / \mathrm{dl}\end{array}$ \\
\hline Sgot & $33.9 \mathrm{u} / \mathrm{l}$ & $\begin{array}{c}\text { Serum } \\
\text { osmolarity }\end{array}$ & 328 \\
\hline
\end{tabular}

\section{Table 2}

\begin{tabular}{|l|c|}
\hline HBA1c & 16.4 \\
\hline C peptide $(0.81-3.85)$ & $<0.05$ \\
\hline GAD 65 IgG(<20) & 289 IU/ml \\
\hline HIV, Hepatitis B , Hepatits c & Negative \\
\hline
\end{tabular}
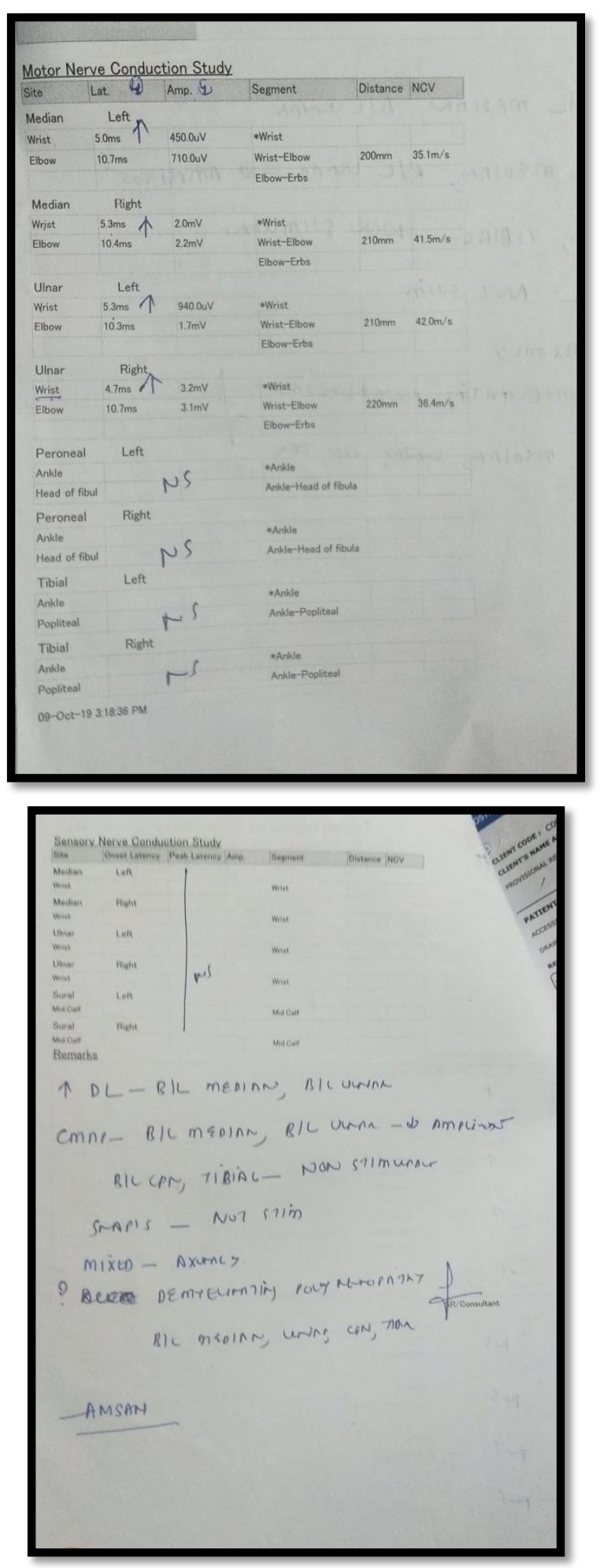

\section{Discussion}

Here we reported a women with DKA followed by the development of GBS. The diagnosis of GBS was made based on history of bilateral and flaccid weakness, absent DTR, nerve conduction study and cerebrospinal fluid analysis. There are only four case reports of the association of DKA and GBS, to our knowledge, in the literature $e^{4,5,6}$. 
We diagnosed our patient as DKA on the basis of ABG, serum osmolarity. Patient had high level of HbA1c which suggested that she had poorly controlled diabetes for certain period of time. Her $\mathrm{C}$ peptide level were low and autoantibodies were present hence we diagnosed as type $1 \mathrm{DM}$.

$70 \%$ of cases of GBS occur 1-3 week after an acute infectious process, usually respiratory or gastrointestinal. GBS association has been seen post h1n1 vaccination, lymphoma, SLE, HIVseropositive individuals. ${ }^{3}$ In above case there was no history of any of above mentioned event. Rouanet - Larriviere et al reported a concept that both type 1 diabetes and GBS might share an autoimmune mechanism which might be triggered by a common event, viral infection in particular. ${ }^{6}$ Electrodiagnostically GBS has various variant, the most common is acute inflammatory demyelinating polyneuropathy (AIDP) [73.8\%]. Other variants are acute motor axonal neuropathy (AMAN), acute motor sensory axonal neuropathy (AMSAN), Miller fisher syndrome. The AMSAN variant is very rare and has worse prognosis and delayed recovery as seen in the above case that despite giving IvIg and doing physiotherapy the weakness does not improved significantly.

The csf finding in a patient of GBS is albumincytological dissociation consisting of an elevated CSF protein level $(100-1000 \mathrm{mg} / \mathrm{dl})$ without accompanying pleocytosis. A transient increase in the CSF white blood count (10-100/ul) occurs on occasion and as shown in the above case patient also had raised protein as compared to cell count. ${ }^{3}$ $85 \%$ of patients with GBS achieve full functional recovery within several months to a year. The outlook is worst in patient with severe proximal motor and sensory damage. ${ }^{3}$

\section{Conclusion}

GBS is an acute, frequently severe, and fulminant polyradiculoneuropathy that is autoimmune in nature.GBS has been reported post infectious, post vaccination, lymphoma, HIV, SLE. DKA has been reported as a cause of GBS.
Declaration of Patient Consent: The authors certify that they have obtained all appropriate consent forms. The patient understands that name and initials will not be published and due efforts will be made to conceal identity, but anonymity cannot be guaranteed.

\section{Conflict of Interest: Nil \\ Source of Support and Sponsorships: Nil}

\section{Reference}

1. Yuki N, Hartung $\mathrm{H}$ Guillain-Barre syndrome. N Engl J Med 2012;366:2294304.

2. Govoni V, Granieri E. Epidemology of the Guillain-Barre syndrome. Curr Opin Neurol.2001;14:605-618.

3. Stephen L.hauser, Anthony A. Amato . Guillain-Barre Syndrome and other immune- mediated Neuropathies. In : Kasper D L, Hauser S L , Jameson J L, Fauci AS, Longo DL, Loscalzo J editors. Harrison's Principle of internal Medicine. $19^{\text {th }}$ edition. New York : McGraw hill;2015.p.3225-3232.

4. Noviello TB, Noviello TC, Purisch S et al. diabetic ketoacidosis associated GBS. Arq Bras Endocrinol Metabol2008;52:562565.

5. Fujiwara S. Oshika H, Motoki K,et al. Diabetic ketoacidosis associated with Guillian-Barre syndrome with autonomic dysfunction. Nippon Naika Gakkai Zasshi2000; 89:1398-1414 .

6. Rouanet-Larriviere M, Vital C, Arne P, Favarel-Garrigues JC, Gin H, Vital A. Guillian barre syndrome occurring in two women after ketoacidosis comatose state disclosing an insulin- dependent diabetes mellitus. J Peripher Nerv Syst 200;5:2731. 